\begin{tabular}{|c|c|c|}
\hline & Int.J.Curr.Microbiol.App.Sci (2021) 10(09): 411-418 & \multirow{4}{*}{ 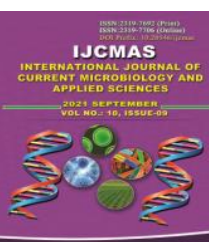 } \\
\hline & \multirow{4}{*}{$\begin{array}{l}\text { International Journal of Current Microbiology and Applied Sciences } \\
\text { ISSN: 2319-7706 Volume } 10 \text { Number } 09 \text { (2021) } \\
\text { Journal homepage: http://www.ijcmas.com }\end{array}$} & \\
\hline & & \\
\hline \begin{tabular}{|l} 
EXCELLENT \\
\end{tabular} & & \\
\hline PUBLIS & & www.ijemas.com \\
\hline
\end{tabular}

\title{
In-vitro Efficacy of PGPR on the Management of Rhizoctonia solani (KUHN) Causing Sheath Blight of Rice
}

\author{
K. Soundarya*, P. Renganathan and A. Eswaran \\ Department of Plant Pathology, Faculty of Agriculture, Annamalai University, \\ Annamalai Nagar, Chidambaram, Tamil Nadu - 608 002, India \\ *Corresponding author
}

\section{A B S T R A C T}

Keywords

Antifungal activity,

R. solani,

P. fluorescens,

Mycelial growth,

Pathogenicity

Article Info

Accepted:

15 August 2021

Available Online:

10 September 2021
Besides, the inherent hazards, negative public perceptions about the adverse environmental pollution of chemical pesticides, an alternative control methods are needed. Bio-stimulants are eco-friendly alternative to chemical pesticides because of their minimal impact on human health and environment, while ensuring optimal increase of crop yield, quality and tolerance to biotic stress. The soil has an enormous untapped potential of microbes, showing antagonistic effects against soil borne plant pathogenic organisms. This work validates a procedure to select one of the best Plant Growth Promoting Rhizobacteria (PGPR) as potential active ingredients for controlling Sheath blight of rice, incited by Rhioctonia solani (Kuhn). It is one of the most important Necrotrophic fungal diseases of rice with approximately $58 \%$ yield reduction in test plots of susceptible cultivars. It was arduous to manage the disease, therefore by investigating the bio-control potential of Pseudomonas fluorescens for the successful management of $R$. solani causing sheath blight disease. The results showed that the bacterial antagonist $P$. fluorescens has exhibited strong inhibition against $R$. solani with 76.40 Per cent over control in dual culture technique. With regard to poisoned food technique the culture filtrates of $P$. fluorescens $\left(\mathrm{Pf}_{3}\right)$ at 15 and 20 per cent conc. completely inhibited the mycelial growth of $R$. solani. In addition to the disease control, the isolate $\mathrm{Pf}_{3}$ recorded the maximum root and shoot length; with germination percentage (96.18) and vigour index (2429.50) thereby it promotes plant growth and seed germination.

\section{Introduction}

Rice is a predominant crop, belonging to the Family Gramineae and the Genus Oryza. Oryza sativa and Oryza glaberrima are the two major cultivated species (Pareja et al., 2011). Rice cultivation started at the $15^{\text {th }}$ century in South East Asia and spread to India, china and Japan. Among the biotic stress factors affecting rice crop, the loss inflicted by pathogen, insect pests and nematodes are considerably more significant. The most important rice diseases like blast, sheath blight, stem rot, grain discoloration and 
bacterial blight causing more damage to the crop (Sharma et al., 2018). Of that, Rice sheath blight caused by Rhizoctonia solani Kuhn. [Sexual stage of $R$. solani was Thanatephorus cucumeris (A.B. Frank) Donk)], it is a universal soil saprotrophic and facultative plant parasite (Anees et al., 2010) and also found to be known as soil-borne hemibiotrophic pathogen, with approximately $58 \%$ yield reduction in test plots of susceptible cultivars (Kouzai et al., 2018). R. solani have 14 anastomosis group placed in AG-1 IA (Gonzalez-Vera et. al. 2010) The disease occurs near the water level after the infection of sheath turn in to softness leads the infection spreads to healthy plant parts resulting development of water soaked lesions and dormant sclerotia or mycelium presented in surface of the water and soil (Tsiboe et al., 2017). The pathogen survive as sclerotia under unfavourable condition and it may spherical or irregular shaped and measure 4-5 $\mathrm{mm}$ in diameter, dark brown to black in colour, basidia and basidiospores are produced and viability for upto 3 years by its saprophytic nature (Kumar et al., 2009). Sclerotia may move from one field to another through irrigation water and during movement they may produce mycelia and secondary or tertiary sclerotia (IRRI 1973). Depending upon the age of the plant, time of infection and severity, it causes yield loss to the extent of 5.9 to 69 per cent. (Roy, 1993) The maximum disease development was recorded at a temperature level of $25-30^{\circ} \mathrm{C}$ and $80-100$ per cent RH (Bhunkal et al., 2015) also by applying high amount of nitrogenous fertilizer (Akash Datta et al., 2017).

Synthetic fungicides are currently used as primary means for the control of plant disease. Besides, the inherent hazards alternative control methods are needed because of the negative public perceptions about the development of resistance by the pathogens, environmental pollution and high development cost of new chemicals (Lamichhane et al., 2017). The microbial antagonist like Plant Growth Promoting Rhizobacteria (PGPR) offers a promising ability in controlling the disease (Nie et al., 2015). Meanwhile, it enhance induced systemic resistant (ISR) fortifying the physical and mechanical strength of cell wall and changing physical and chemical reaction of host leading to synthesis of defense chemicals against pathogen (Jayalakshmi et al., 2009). Among the PGPR's, the bio-control potential of Pseudomonas fluorescens was undertaken to investigate in the present study for the successful management for combating the sheath blight incidence.

\section{Materials and Methods}

\section{Isolation, maintenance and identification of the test pathogen}

Diseased rice plants with characteristic symptoms of sheath blight disease were collected from ten traditional rice growing areas of Mayiladuthurai district, Tamil Nadu. The infected portion of the sheath was cut into small bit, surface sterilized with $0.1 \%$ sodium hypochlorite solution for $1 \mathrm{~min}$ and washed thrice with sterile distilled water. Further, a piece of specimen was transferred to sterile Petri dishes containing PDA medium. The plates were incubated at room temperature $\left(28 \pm 2{ }^{\circ} \mathrm{C}\right)$ for 5 days and the isolates were purified by single hyphal tip method. Characterization and identification of viruent isolate of $R$. solani was confirmed and maintained on PDA slant for further studies.

\section{Isolation and characterization of bacterial antagonist ( $P$. fluorescencs)}

Rhizoplane-colonizing $P$. fluorescens was isolated from fresh roots of paddy grown in different locality of Mayiladuthurai district and were designated as $\mathrm{Pf}_{1}-\mathrm{Pf}_{8}$. The soil 
particles loosely adhering to the roots were teased out and used for the isolation of $P$. fluorescens. A soil suspension was prepared from each rhizosphere sample by shaking $1 \mathrm{~g}$ of soil sample in $10 \mathrm{ml}$ of sterile dist. water and serial dilutions were made. $1 \mathrm{ml}$ of soil suspension from aliquot dilutions $\left(10^{-5}\right.$ to $\left.10^{-8}\right)$ was aseptically added to sterile Petri dishes containing $20 \mathrm{ml}$ of sterile King's B medium and incubated at $28 \pm 2{ }^{\circ} \mathrm{C}$ for $48 \mathrm{~h}$ after incubation, well separated individual colonies with yellow green and blue white pigments were marked and detected by viewing under UV light. Also, the colony and type of colony, shape of cell were observed. The individual colonies were picked up with sterile loop and transferred to fresh King's B slants and the pure cultures so obtained were stored in refrigerator at $4{ }^{\circ} \mathrm{C}$ for further use.

\section{Efficacy of bacterial antagonists against R. solani (in vitro)}

\section{Dual culture technique}

$20 \mathrm{ml}$ of PDA medium was poured into sterile petridishes. After solidification, 10 days old, $9 \mathrm{~mm}$ disc of $R$. solani culture was inoculated $1 \mathrm{~cm}$ away from the edge of the petridish. At opposite end of the sterile plate dish 2 days old culture of $P$. fluorescens one $\mathrm{cm}$ long streak was gently made onto the medium and incubated at room temperature $\left(28 \pm 2^{\circ} \mathrm{C}\right)$ until the control plates covered by the pathogen. The effective antagonists were identified based on the inhibition of the growth of the pathogen. The radial mycelia growth of the pathogen and percent reduction over control was calculated by using the formula (Vincett, 1927)

Per cent inhibition $(\mathrm{I})=\frac{\mathrm{C}-\mathrm{T}}{\mathrm{C}} \times 100$

$\therefore$ C- Mycelial growth of pathogen in control; $\mathrm{T}$ - Mycelial growth of pathogen in dual plate.
Bioassay of culture filtrates on the Mycelial dry weight of $R$. solani (Liquid medium assay)

The culture filtrates of the $P$. fluorescens were separately incorporated into sterilized $50 \mathrm{ml}$ PDA broth at 10, 20, 30 and 40 per cent by adding the calculated quantity of the culture filtrates to the broth. The PDA broth without the culture filtrate served as control. The amended media were dispensed in $250 \mathrm{ml}$ Erlenmeyer flasks, autoclaved at $1.4 \mathrm{~kg} / \mathrm{cm}^{2}$ for $20 \mathrm{~min}$ and cooled. The each flask was inoculated separately with a 10 day old $9 \mathrm{~mm}$ culture disc of $R$. solani and incubated at room temperature $\left(28 \pm 2^{\circ} \mathrm{C}\right)$ for fifteen days. Three replications were maintained for each medium. After incubation the mycelial mat was filtered through a pre weighed Whatman No. 1 filter paper and then dried in hot air oven at $60^{\circ} \mathrm{C}$ till a constant weight was obtained. The mycelial dry weight was calculated by subtracting from the weight of the filter paper and recorded. The results were expressed as per cent growth inhibition over control.

\section{Preparation of the cultural filtrate of $P$. fluorescens}

The effective $P$. fluorescens isolates were inoculated into Erlenmeyer flasks containing $50 \mathrm{ml}$ of sterilized King's B broth and kept on a rotary shaker at $100 \mathrm{rpm}$ for $48 \mathrm{~h}$. Then the cultures were filtered through bacteriological filter under vacuum and the filtrates thus obtained were used for the studies.

\section{Efficacy of culture filtrates on the mycelial growth of $R$. solani}

The culture filtrate of the antagonists was separately incorporated into sterilized PDA media at 10, 20 and 30 per cent by adding the calculated quantity of the culture filtrates to the medium by means of a sterile pipette. The 
PDA medium without the culture filtrate served as control. The amended media were transferred to sterile Petri dishes separately @ $15 \mathrm{ml}$ and allowed to solidify. Each plate was inoculated at the centre with five days old (9mm) PDA culture disc of $R$. solani. Three replications were maintained for each treatment. The diameter of the mycelia growth (in $\mathrm{mm}$ ) of $R$. solani was measured when the mycelia growth fully covered the control plates.

\section{Plant growth promotion- Roll towel method}

Plant growth promoting activity of the antagonists was based on the seedling vigour index by the standard roll towel method. The germination paper was soaked in water for 2-4 hrs. The 25 seeds treated with the selected antagonists were kept over the pre-soaked germination paper. The seeds were held in position by placing another pre-soaked germination paper strip over it and gently pressed. The sheets along with seeds were then rolled carefully ensuring no pressure on the seed, wrapped with polythene sheet to reduce surface evaporation and kept in germination chamber in an upright position and incubated at room temperature at $28 \pm 2^{\circ} \mathrm{C}$ for ten days. Three replications were maintained for each treatment. The root length and shoot length of individual seedlings were measured and the per cent germination of seeds was also calculated. The seedling vigour index was calculated by (Abdul Baki and Anderson 1973).

The germination percentage was calculated by using the formula,

\section{Germination(\%)$$
=\frac{\text { Number of seeds germinated }}{\text { Total number of seeds sown }} \times 100
$$

The vigour index was calculated by using the formula

Vigour index $=($ Shoot length + Root length $) \times$ Germination (\%)

\section{Results and Discussion}

Efficacy of bacterial antagonists against $\boldsymbol{R}$. solani (in vitro)

\section{Dual culture technique and Liquid medium assay}

Eight isolates of $P$. fluorescence were isolated from different parts of Tamil Nadu and tested for their efficacy against $R$. solani. All the isolates significantly reduced the mycelial growth of the pathogen over control under dual culture technique. The results presented in Table 1. revealed varying degree of antagonism by the isolates of $P$. fluoresecens against $R$. solani $\left(\mathrm{RS}_{7}\right)$ among the isolates, $\mathrm{Pf}_{3}$ produced significantly the maximum inhibition zone $(13.43 \mathrm{~mm})$ and minimum mycelial growth $(21.24 \mathrm{~mm})$ accounting for 76.40 per cent reduction on the mycelial growth of $R$. solani $\left(\mathrm{RS}_{7}\right)$ over control.

This was followed by isolate $\mathrm{Pf}_{1}$ which recorded 73.64 per cent reduction on the mycelial growth over control. The isolate $\mathrm{Pf}_{7}$ was the least effective as it produced only the inhibition zone of $5.18 \mathrm{~mm}$ and 62.22 per cent reduction on the mycelial growth. Suman et al., (2017) reported that $P$. fluorescence in dual culture technique effectively inhibited the mycelial growth of $R$. solani.

The mycelial dry weight of the pathogen was also recorded on 10,20, 30 and 40 per cent concentration of culture filtrate of the antagonists. 
Table.1 Antagonistic activity of native isolates of $P$. fluorescens against $R$. solani $\left(\mathrm{RS}_{7}\right)$ (Dual culture technique)

\begin{tabular}{|c|c|c|c|c|c|c|c|c|}
\hline \multirow{2}{*}{ Isolates } & \multicolumn{3}{|c|}{ R. solani $\left(\mathbf{R S}_{\mathbf{7}}\right)$} & \multicolumn{5}{c|}{$\begin{array}{c}\text { Mycelial dry weight } \\
\text { (mg/50 ml broth) }\end{array}$} \\
\cline { 2 - 10 } & $\begin{array}{c}\text { Mycelial } \\
\text { growth } \\
(\mathbf{m m})\end{array}$ & $\begin{array}{c}\text { Per cent } \\
\text { inhibition } \\
\text { over control }\end{array}$ & $\begin{array}{c}\text { Inhibition } \\
\text { zone }\end{array}$ & $\mathbf{1 0 \%}$ & $\mathbf{2 0 \%}$ & $\mathbf{3 0 \%}$ & $\mathbf{4 0 \%}$ & Mean \\
\hline $\mathbf{P f}_{\mathbf{1}}$ & $23.72^{\mathrm{b}}$ & 73.64 & 11.76 & 233 & 193 & 105 & 35 & $141.5^{\mathrm{b}}$ \\
\hline $\mathbf{P f}_{\mathbf{2}}$ & $29.17^{\mathrm{d}}$ & 67.58 & 7.93 & 296 & 253 & 135 & 46 & $182.5^{\mathrm{d}}$ \\
\hline $\mathbf{P f}_{\mathbf{3}}$ & $21.24^{\mathrm{a}}$ & 76.40 & 13.43 & 217 & 165 & 85 & 27 & $123.5^{\mathrm{a}}$ \\
\hline $\mathbf{P f}_{\mathbf{4}}$ & $26.43^{\mathrm{c}}$ & 70.63 & 9.82 & 249 & 225 & 115 & 38 & $156.75^{\mathrm{c}}$ \\
\hline $\mathbf{P f}_{\mathbf{5}}$ & $28.78^{\mathrm{d}}$ & 68.02 & 7.35 & 269 & 239 & 125 & 40 & $168.25^{\mathrm{d}}$ \\
\hline $\mathbf{P f}_{\mathbf{6}}$ & $33.77^{\mathrm{e}}$ & 62.47 & 5.73 & 325 & 258 & 150 & 49 & $195.5^{\mathrm{e}}$ \\
\hline $\mathbf{P f}_{\mathbf{7}}$ & $33.64^{\mathrm{e}}$ & 62.62 & 5.18 & 315 & 266 & 139 & 53 & $193.25^{\mathrm{e}}$ \\
\hline $\mathbf{P f}_{\mathbf{8}}$ & $35.19^{\mathrm{f}}$ & 60.90 & 3.71 & 346 & 263 & 130 & 54 & $198.25^{\mathrm{f}}$ \\
\hline $\mathbf{C o n t r o l}$ & $90.00^{\mathrm{f}}$ & - & - & 390 & 390 & 390 & 390 & 390 \\
\hline
\end{tabular}

*Values in the column followed by common letters do not differ significantly by DMRT $(\mathrm{P}=0.05)$

Table.2 Effect of culture filtrate of native isolates of $P$. fluorescens on the mycelial growth of $R$. solani $\left(\mathrm{RS}_{7}\right)$ (Poisoned food technique)

\begin{tabular}{|c|c|c|c|c|c|c|c|c|}
\hline \multirow{2}{*}{$\begin{array}{c}\text { Isolates } \\
\text { No. }\end{array}$} & \multicolumn{8}{|c|}{ Mycelial growth (mm) } \\
\hline & $\begin{array}{c}5 \% \\
\text { Concentr } \\
\text { ation }\end{array}$ & $\begin{array}{c}\text { Per cent } \\
\text { inhibition } \\
\text { over } \\
\text { control }\end{array}$ & $\begin{array}{c}10 \% \\
\text { concentra } \\
\text { tion }\end{array}$ & $\begin{array}{c}\text { Per cent } \\
\text { inhibition } \\
\text { over } \\
\text { control }\end{array}$ & $\begin{array}{c}15 \% \\
\text { Concentration }\end{array}$ & $\begin{array}{c}\text { Percent } \\
\text { inhibition } \\
\text { over } \\
\text { control }\end{array}$ & $\begin{array}{c}20 \% \\
\text { Concentration }\end{array}$ & $\begin{array}{c}\text { Per cent } \\
\text { inhibition } \\
\text { over } \\
\text { control }\end{array}$ \\
\hline $\mathbf{P f}_{1}$ & $25.33^{\mathrm{b}}$ & 71.85 & $17.66^{\mathrm{b}}$ & 80.37 & $7.65^{\mathrm{b}}$ & 91.50 & $1.60^{\mathrm{b}}$ & 98.22 \\
\hline $\mathbf{P f}_{2}$ & $37.65^{\mathrm{d}}$ & 58.26 & $22.05^{\mathrm{d}}$ & 75.50 & $11.65^{\mathrm{d}}$ & 87.05 & $11.65^{\mathrm{d}}$ & 87.05 \\
\hline $\mathbf{P f}_{3}$ & $20.00^{\mathrm{a}}$ & 77.77 & $11.32^{\mathrm{a}}$ & 87.42 & $0.00^{\mathrm{a}}$ & 100.00 & $0.00^{\mathrm{a}}$ & 100.00 \\
\hline $\mathbf{P f}_{4}$ & $30.00^{c}$ & 66.66 & $20.66^{c}$ & 77.04 & $8.60^{c}$ & 90.44 & $1.82^{\mathrm{c}}$ & 97.97 \\
\hline $\mathbf{P f}_{5}$ & $37.56^{d}$ & 58.16 & $24.60^{d}$ & 72.66 & $19.20^{\mathrm{d}}$ & 78.66 & $19.20^{\mathrm{d}}$ & 78.66 \\
\hline $\mathbf{P f}_{6}$ & $39.00^{\mathrm{e}}$ & 56.66 & $28.00^{\mathrm{e}}$ & 68.88 & $19.33^{\mathrm{e}}$ & 78.52 & $19.33^{\mathrm{e}}$ & 78.52 \\
\hline $\mathbf{P f}_{7}$ & $40.66^{\mathrm{f}}$ & 54.82 & $30.00^{f}$ & 66.66 & $20.10^{f}$ & 77.66 & $20.10^{f}$ & 77.66 \\
\hline $\mathbf{P f}_{8}$ & $43.20^{f}$ & 52.00 & $31.32^{f}$ & 65.20 & $23.32^{f}$ & 74.08 & $23.32^{f}$ & 74.08 \\
\hline Control & $90.00^{\mathrm{g}}$ & - & $90.00^{f}$ & - & $90.00^{\mathrm{g}}$ & - & $90.00^{\mathrm{g}}$ & - \\
\hline
\end{tabular}

* Mean of three replication

* Values in the column followed by common letters do not differ significantly by DMRT $(\mathrm{P}=0.05)$ 
Table.3 Efficacy of $P$. fluorescens on the plant growth promotion under in vitro conditions

\begin{tabular}{|c|c|c|c|c|}
\hline Isolates & $\begin{array}{c}\text { Mean root } \\
\text { length } \\
\text { (cm) }\end{array}$ & $\begin{array}{c}\text { Mean shoot } \\
\text { length } \\
\text { (cm) }\end{array}$ & $\begin{array}{c}\text { Germination } \\
\text { percentage } \\
(\mathbf{\%})\end{array}$ & Vigour index \\
\hline $\mathbf{P f}_{\mathbf{1}}$ & 15.97 & 8.10 & 95.75 & $2304.70^{\mathrm{b}}$ \\
\hline $\mathbf{P f}_{\mathbf{2}}$ & 13.98 & 7.42 & 93.40 & $1998.76^{\mathrm{d}}$ \\
\hline $\mathbf{P f}_{\mathbf{3}}$ & 17.10 & 8.16 & 96.18 & $2429.50^{\mathrm{a}}$ \\
\hline $\mathbf{P f}_{\mathbf{4}}$ & 15.72 & 7.90 & 95.15 & $2247.44^{\mathrm{b}}$ \\
\hline $\mathbf{P f}_{\mathbf{5}}$ & 14.20 & 7.78 & 94.53 & $2077.76^{\mathrm{c}}$ \\
\hline $\mathbf{P f}_{\mathbf{6}}$ & 12.36 & 5.86 & 90.28 & $1644.90^{\mathrm{f}}$ \\
\hline $\mathbf{P f}_{\mathbf{7}}$ & 13.58 & 6.35 & 92.35 & $1840.53^{\mathrm{e}}$ \\
\hline $\mathbf{P f}_{\mathbf{8}}$ & 11.31 & 5.28 & 90.05 & $1493.92^{\mathrm{g}}$ \\
\hline $\mathbf{C a r b e n d a z i m ~ 5 0 \% ~}_{\mathbf{W P}}$ & 16.56 & 8.65 & 96.11 & $2422.93^{\mathrm{a}}$ \\
\hline $\mathbf{C o n t r o l}$ & 10.55 & 4.33 & 78.15 & $1162.87^{\mathrm{h}}$ \\
\hline
\end{tabular}

* Values in the column followed by common letters do not differ significantly by DMRT $(\mathrm{P}=0.05)$

All the treatments were found to be effective in reducing the growth of pathogen. However, among the different treatments $P$. fluorescens isolates $\left(\mathrm{Pf}_{3}\right)$ showed minimum mycelial growth recording 217, 165, 85and $27 \mathrm{mg} / 50$ $\mathrm{ml}$ broth at 10, 20, 30 and 40 per cent conc. respectively, followed by $\mathrm{Pf}_{1}$ and $\mathrm{Pf}_{4}$ recording a vegetative growth of $233,193,105,35$ and $249,225,115$ and $38 \mathrm{mg} / 50 \mathrm{ml} / \mathrm{broth}$ respectively (Table 1). The results of the experiment showed the superiority of $\mathrm{Pf}_{3}$ isolate. The secondary metabolites like 2,4, diacetylphloroglucinol, oligomycin, oomycinA, phenazzine, pyoluterin, pyrolnitrin, pyocyanin, iturin, hydrogen cyanide, antibiotics and lytic enzymes, $\beta$ 1,3glucanase and chitinase were reduced by $P$. fluorescence (Kumar et al., 2013; Mishra and Arora 2017; Purkayastha et al., 2018).

\section{Efficacy of culture filtrates on the mycelial growth of $R$. solani $\left(\mathrm{RS}_{7}\right)$}

Studies on the effect of different conc. of culture filtrate of $P$. fluorescens on the mycelial growth of $R$. solani $\left(\mathrm{RS}_{7}\right)$ under in vitro condition. The results revealed that the culture filtrate of isolate $\mathrm{Pf}_{3}$ totally inhibited the mycelial growth of $R$. solani $\left(\mathrm{RS}_{7}\right)$ at $15 \%$ and $20 \%$ conc. under in vitro condition followed by the isolate $\mathrm{Pf}_{1}$ which recorded 98.22 per cent inhibition of mycelial growth over control at $20 \%$. However, incorporation of $5 \%$ conc. of culture filtrate was not effective against $R$. solani $\left(\mathrm{RS}_{7}\right)$ due to irrespective of various isolates tested in the present investigation (Table 2). Similar findings was reported by (Tewari and arora 2016; Neha 2016; Meena et al., 2018).

Bioassay of $\boldsymbol{P}$. fluorescens on the seed germination and plant growth promotion under in vitro conditions

The seed treatment with $P$. fluorescence was induced plant growth promotion in paddy under in vitro condition. However, the data depicted in Table 3 revealed that all the eight isolates of $P$. fluorescens increase the vigour index of rice seedlings. Among them, the isolate $\mathrm{Pf}_{3}$ recorded the maximum root (17.10) and shoot (8.16) length, germination percentage (96.18) and vigour index (2429.50). This was followed by the isolate $\mathrm{Pf}_{1}$ recorded $15.97 \mathrm{~cm}, 8.10 \mathrm{~cm}, 95.75 \%$ root and shoot length, and germination percentage respectively. $\mathrm{Pf}_{8}$ isolate recorded the least vigour. 
Kloepper and scroth 1981], reported that specific rhizosphere bacteria applied to seeds could colonize roots and promote rhizobacteria PGPR. Several workers have reported about the growth promoting effect of Pseudomonas in various crops (Chatterjee et al., 2012; Singh et al., 2015; Prasad et al., 2016). The result of present study is in line with these earlier reports

The use of $P$. fluorescens for the management of $R$. solani without chemical pesticides will be of interest to the organic fertilizer industry. In addition to disease control, $P$. fluorescens provided plant growth promotion along with notable benefits. Hence $P$. fluorescens were found to superior in inhibiting the growth of R. solani

\section{References}

Abdul Baki A, Anderson J D (1973) Vigour determination in soya bean seed by multiple criteria. Crop Sci 13: 630-633.

Akash Datta Sai Shiv A and Krishnaprasad Vurukonda (2017) Rice Sheath Blight: A Review of the Unsung Fatal Disease. Trends in Bio sci 10 (45): 9216-9219

Anees M, Edel-Hermann V and Steinberg C (2010) Buildup of patches caused by Rhizoctonia solani. Soil Biology and Biochemistry 42: 1661-1672

Bhunkal N, Singh Ram and Mehta N (2015) Assessment of losses and identification of slow blighting genotypes against sheath blight of rice. J Mycol Plant Pathol 45:285-292

Chatterjee S, Sau G B, Sinha S, Mukherjee S K (2012) Effect of coinoculation of Plant Growth Promoting Rhizobacteria on the growth of amaranth plants. Arch Agro Soil Sci 58 (12): 1387 - 1397.

Gonzalez-vera A D, Bernardes - de - Assis J, Zala M, McDonald B A, CorreaVictoria $\mathrm{F}$ and Graterol-Mature E J (2010) Divergence between sympatric rice and maize- infecting population of Rhizoctonia solani AG-1 IA from Latin America. Phytopathol 100:172-182

Jayalakshmi S K, Raju S, Rani S U, BEnagi V I and sreeramulu K (2009) Trichoderma harzianum $\mathrm{L} 1$ as a potential source for lytic enzymes and elicitor defence responses in chickpea (Cicer arietinum L.) against wilt disease caused by Fusarium oxysporum f. sp. Ciceri. Australian J of Crop Sci 3: 44-52.

Kouzai Y, Noutoshi Y, Inoue K Shimizu M, Onda Y and Mochida K (2018) Benzothiadiazole, a plant defense inducer, negatively regulates sheath blight resistance in Brachypodium distachyon. Scientific Reports 8: 17358 DOI: $10.1038 / \mathrm{s} 41598-018-35790-\mathrm{w}$

Kumar A and Pratush A (2013) Phosphate solubilizing bacterial diversity from the rhizospheric soils of sub-temperature region of Himachal Pradesh. Vegetos 26: $143-150$

Kumar K V K, Reddy M S, Kloepper J W, Laerence K S, Groth D E, Miller M E (2009) Sheath blight disease of rice (Oryza stiva L.). An overview Biosci Biotechnol Res Asia 6:465-480

Lamichhane J R, Durr C, Schwanck A A, Robin M H, Sarthou J P, Cellier V, Messean A, Aubertot J N (2017) Integrated management of damping-off diseases. A review. Agronomy for Sustainable Development, Springer, Int J Curr Microbiol App Sci 8(2):566-579

Meena (2018) Screening of sesame (Sesamum indicum L.) germplasm against major diseases. $\mathbf{J}$ of Pharmacognosy and Phytoche 1466-1468

Mishra J and Arora (2017) Scondary metabolites of fluorescent Pseudomonas in biocontrol of phytopathogens for sustainable agriculture. App Soil Ecol

Neha KV, Balabaskar P, Naveenkumar R (2016) Survey and occurrence of Rhizoctonia solani (Kuhn) causing 
sheath blight of rice and in vitro efficacy of bacterial antagonists against Rhizoctonia solani (Kuhn). Journal of environmental biology Vol.371 4211427

Nie M, Bell C, Wallenstein M D \& Pendall E (2015). Increased plant productivity and decreased microbial respiratory $C$ loss by Plant Growth-Promotting Rhizobacteria under elevated CO2. Scientific Reports 5.9212.

$P$. fluorescens against sheath blight in rice by $R$. solani. Int $\mathrm{J}$ of current Microbiol and App Sci 6(4): 2581-2589.

Pareja L, Fernande Z - Alba AR, Cesio U, Heinzen H (2011) Analytical methods for pesticide residuces in rice. Trac Anal chem 30: 270-291 https: //doi.org/10.1016/j.trac.2010.12.001

Prasad B, Kumar A, singh A V, Kumar A (2016) Plant growth and seed yield attributes as influenced by bacterial isolates under glass house. Progre Res $11(4): 2573-2576$

Purkayastha G D, Mangar P, Saha A, Saha D (2018) Evaluation of the biocontrol efficacy of a Serratia marcescens strain indigenous to tea rhizosphere for the management of root rot disease in tea. PLoS One 13(2):e0191761

Roy, A K. (1993). Sheath blight of rice in
India. Indian Phytopathology 46: 197205.

Sharma A, McClung A M, Pinson S R, Kepiro J L, Shank A R, Tabien R E, Fjellstrom $R$ (2018) Genetic mapping of sheath blight resistance QTLs within tropical japonica rice cultivars. Crop Sci 49(1);256-264

https;//doi.org/10.2135/cropsci2008.03. 0214

Singh R, Murti P, Mehilal S, Tomer A and Prasad D (2015) Virulence diversity in Rhizoctonia solani causing sheath blight in rice pethogenicitya. J Plant Pathol Microbiol 6: 1-8

Suman B, Gopal A V, Reddy R S, Triveni S and Nissipaul M (2017) Study the efficacy of

Tewari S and N K Arora (2016) Fluorescent Pseudomonas sp. PF17 as an efficient plant growth regulator and biocontrol agent sunglower crop under saline conditions. Symbiosis 16: 51-57

Tsiboe F, Nalley L L, Durand A, Thoma G, Shew A (2017) The economics and environmental benefits of sheath blight resistance in rice. $\mathrm{J}$ Agric Resour 42:215-235

Vincent J M (1927). Distribution of fungal hyphae in the presence of certain inhibitors. Nature 159: 850.

\section{How to cite this article:}

Soundarya, K., P. Renganathan and Eswaran, A. 2021. In- vitro Efficacy of PGPR on the Management of Rhizoctonia solani (KUHN) Causing Sheath Blight of Rice. Int.J.Curr.Microbiol.App.Sci. 10(09): 411-418. doi: https://doi.org/10.20546/ijcmas.2021.1009.048 